УДК 657.3:658.14/.17:005.935:006.03

DOI: 10.15673/fie.v13i2.2044

Ткачук Г.О.

доктор економічних наук, доцент кафедра обліку та аудиту

E-mail: talla2007@ukr.net

ORCID ID: 0000-0001-6937-6223
Іванченкова Л.В.

доктор економічних наук, професор кафедра обліку та аудиту

E-mail: ivanchenkovalarisa@gmail.com

ORCID ID: 0000-0002-8461-7846

\author{
Скляр Л.Б. \\ кандидат економічних наук, доцент \\ кафедра обліку та аудиту \\ Одеська національна академія харчових технологій \\ вул. Канатна, 112, м. Одеса, Україна, 65039 \\ E-mail: sklyarlarisa17@gmail.com \\ ORCID ID: 0000-0002-8332-8823
}

\title{
ІНТЕГРОВАНИЙ ОБЛІК ТА ЗВІТНІСТЬ В УПРАВЛІННІ КОРПОРАТИВНОГО ПІДПРИЕМСТВА: ТЕОРЕТИЧНІ АСПЕКТИ ЗАПРОВАДЖЕННЯ ТА КОНТРОЛЮ
}

Актуальність напряму наукового дослідження обґрунтовується розширенням інформаційних потреб звітної інформації в умовах процесів глобалізації. Стаття присвячена вивчення проблем формування теоретико-методологічного базису застосування інтегрованого обліку та звітності на корпоративних підприємствах. Визначена сутність та завдання інтегрованої звітності, проаналізовано її відмінні риси; розглянуто передумови розвитку моделі інтегрованої звітності. Визначено місце інтегрованої звітності в системі управління підприємством. В даній статті узагальнено проблемні аспекти застосування інтегрованої звітності для корпоративних підприємств. Означені особливості фрормування структури та змісту інтегрованої звітності. Проведено аналіз структури та змісту Річної інформації емітента цінних паперів. Авторами запропоновано заходи щодо практичного застосування на підприємстві інтегрованого обліку та звітності. Визначено напрямки подальших наукових досліджень.

Ключові слова: бухгалтерський облік, інтегрований облік, фінансова звітність, інтегрована звітність, Міжнародні стандарти бухгалтерського обліку, внутрішньофірмові стандарти, корпоративний контроль, внутрішньогосподарський контроль, управління підприємством

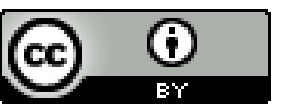

This work is licensed under a Creative Commons Attribution 4.0 International License http://creativecommons.org/licenses/by/4.0/
Постановка проблеми та її зв'язок з важливими науковими та практичними завданнями. Основним джерелом інформації для прийняття рішень стосовно стратегічного розвитку підприємства, інвестування коштів, кредитування бізнес-проектів $€$ фінансова звітність, яка надає інформацію про результати господарської діяльності, фінансовий та майновий стан підприємства. Однак, фінансової інформації недостатньо для висвітленні всіх проблем сучасного бізнесу. Як визначають сучасні наукові дослідження звітна інформація не повинні «концентрувати свою увагу лише на діяльності підприємства та його мікрозовнішньому середовищі, а також повинна сприяти наданню відповіді на актуальні проблеми функціонування соціально-економічних систем, у тому числі на нагальні соціальні, екологічні та управлінські проблеми» [1]. До того ж, недоліком традиційного підходу до укладання та подання даних в фінансовій звітності підприємства є відсутність інформації щодо фінансових та нефінансових ризиків, факторів та напрямів стратегічного розвитку підпри- ємства, стану системи корпоративного управління та контролю, проблематики екологічного та соціального характеру тощо.

Фінансова та статистична звітність підприємства не дозволяють потенційному інвестору отримати повноцінну інформацію для адекватної оцінки вартості бізнесу та прийняття відповідного рішення. До того ж, не всі підприємства та організації зобов'язані оприлюднювати фінансову звітність, доступ до статистичної звітності обмежений, а до управлінської - майже неможливий, якщо не зважати на «промисловий шпіонаж» та «промислову розвідку». Така ситуація зовсім не сприяє залученню інвестиційних коштів для розвитку харчової промисловості. Інтегрована звітність, як комплексна трансформована звітність, що включає показники традиційної фінансової й нефінансової звітності та інформацію управлінських звітів, може стати дієвим інструментом поінформованості користувачів інтегрованої звітності щодо стану та перспектив розвитку підприємства.

Розширення інформаційних можливостей для 
користувачів - важливий крок до забезпечення якості, повноти та достовірності звітних даних, що обгрунтовує актуальність й своєчасність дослідження проблемних аспектів застосування інтегрованого обліку та звітності задля реалізації прийдешніх управлінських цілей.

Аналіз останніх публікацій по проблемі. Тематика інтегрованої звітності та обліку активно вивчається у наукових працях відомих економістів: С. Адамса, Р. Сімнета, К.В. Безверхого, Ф.Ф. Бутинця, С.Ф. Голова, Х. Драгер, В.М. Жука, Р. Дж. Екклза, М.П. Кжуса, П.П. Німчинова, О.В. Олійник, М.А. Проданчука, К.В. Сорокіної, Дж. Серафейма, М.М. Шигун та інших.

Формулювання цілей дослідження. 3 метою дослідження проблематики застосування інтегрованого обліку та звітності на підприємствах харчової промисловості нами поставлені та вирішені такі завдання: ної звітності;

1) розглянуто сутність та завдання інтегрова-

2) узагальнено основні відмінні риси інтегрованої звітності;

3) досліджено зв'язок інтегрованих звітів та функцій управління;

4) досліджено склад звітності акціонерного товариства;

5) запропонувати заходи практичного застосування інтегрованого обліку та звітності для підприємств харчової промисловості.

Виклад основних результатів та їх обгрунтування. Загальне поняття інтегрованої звітності надане Комітетом 3 міжнародної інтегрованої звітності (IIRC). Інтегрована звітність - це процес, який призводить до подання організацією відомостей, які виражаються у випуску фінансового звіту про створення цінностей протягом певного часу. Інтегрований звіт являє собою короткострокове відображення того, як стратегія, управління, результати і перспективи організації в контексті зовнішнього середовища ведуть до створення вартості в коротко-, середньо- i довгостроковій перспективі [2].

Адамс С. та Сімнетт Р. [3] називають інтегровану звітність новою парадигмою звітності, яка є «цілісною, адаптивною, стратегічною, суттєвою i актуальною до різних часових вимірів». Проданчук М.А. [4] вбачає у інтегрованій звітності гармонізацію «фінансової та нефінансової звітності, де узагальнено інформацію про фінансовий стан та результати фінансово-господарської, соціальної та екологічної діяльності підприємств», а Драгер Х. [5] - «виклик образу мислення». Романенко О.А. та Комірна О.В. [6] відносять до змісту інтегрованої звітності інформацію щодо «стратегії, ризиків, стійкості бізнес-моделі підприємства».

Передумовою виникнення концепції інтегрованої звітності стало поширення практики складання єдиного загального корпоративного звіту підприємствами різних країн на початку 2000-х р. (датські компанії «Novozymes» (2002р.) й «Novo Nordisk» (2004 р.) та бразильська компанія «Natura»
(2003 р.)). Цікаво, що головною причиною необхідності формування такого звіту стала банальна економія витрат на процес укладання і оприлюднення звітності.

Завданням запровадження інтегрованої звітності є:

1) отримання інформації про переваги та ймовірні ризики бізнесу;

2) отримання уявлення про стратегію розвитку підприємства;

3) формування достовірного уявлення щодо реальної вартості бізнесу;

4) пошук нових нефінансових ресурсів збільшення ефективності та забезпечення конкурентоспроможності.

Інтегрована звітність має такі відмінні риси в порівнянні із традиційною фінансовою звітністю:

1) застосування інтегрованого мислення, яке передбачає «об'єднання в ціле будь-яких окремих частин» [7] різних звітів підприємства;

2) відображення не тільки фінансового, а й інших видів капіталу;

3) орієнтація на стратегічний взаємозв'язок минулого і майбутнього;

4) розширення часових меж, збільшення довіри і прозорості інформації;

5) гнучкість за рахунок надання підприємствами інформації, яку вони вважають суттєвою;

6) стислість, змістовність та публічність інформації;

7) орієнтація на процеси цифровізації. Інтегрована звітність використовує нові прогресивні технології для забезпечення прилюдного доступу та детального розкриття інформації.

Також до особливостей інтегрованої звітності, що відрізняють їі від інших видів звітності, відносять: «новий підхід до структуризації капіталу підприємства; орієнтацію на створення інформаційного забезпечення вартісно-орієнтованого управління; орієнтацію на висвітлення тих аспектів діяльності підприємства, які впливають на його стратегічну стійкість та довгострокову перспективу» [1].

За останнє десятиліття рух щодо інтеграції звітності набув активного характеру, а саме, 2010 рік - засновано «Міжнародний комітет 3 інтегрованої звітності» (IIRC), 2011 рік - створено «Раду 3 розробки облікових стандартів зі стійкого розвитку» (SASB), 2013 рік - опубліковано документ «G4 Guideliness» організації «Глобальної ініціативи звітності» (GRI) щодо рекомендацій «про порядок подання інформації про стійкий розвиток у звітах різних форматів, зокрема, в інтегрованих звітах» [8].

Дослідження, проведені у 2013 році серед 96 європейських компаній-інвесторів, показали що $92 \%$ iз них погодились 3 тим, що «фінансова та нефінансова інформація повинні бути інтегровані» [9]. Наступний крок - створення обов'язкового стандарту інтегрованої звітності для всіх глобальних компаній, що котируються на біржовому ринку. 
Національні підприємства харчової промисловості поволі опановують практику укладання інтегрованих звітів. Так у 2018 році ЗАТ «Оболонь» опублікувало Звіт про сталий розвиток (GRI3), СП «Вітмарк-Україна» ТОВ - Звіт з прогресу, «Кока-кола Україна» - Звіт про соціальну відповідальність, Nemiroff Україна - екологічний звіт.

Як ми вже зазначали, потреби сучасних користувачів інформації не задовольняються показниками про результати діяльності, фінансовий та майновий стан підприємства, основні напрями грошових потоків, структуру власного капіталу, які представлені у фінансовій звітності. Цікавість потенційних інвесторів поширюється на дані нефінансової звітності (статистичної та спеціальної), яка характеризує напрями реалізації політики корпоративної соціальної відповідальності, а також на зміст управлінської звітності, що традиційно вважається інформацією «для внутрішнього користування». Однак саме управлінська звітність надає інформацію про бізнес-ризики (фінансові, майнові, ризики менеджменту тощо); ефективність окремих господарських операцій, процесів, контрактів; вплив інфляційних процесів, суттєві зміни організації бізнесу та менеджменту; наявність та методи системи внутрішнього контролю.

Економічні коментарі надаються стосовно характеристики (опису) бізнесу, напрямів його стратегічного розвитку, облікової політики підприємства; опису факторів, що впливають на бізнес; характеристики зовнішніх комунікацій тощо. В економічно розвинутих країнах така інформація подається у формі Звіту про сталий (стійкий) розвиток.

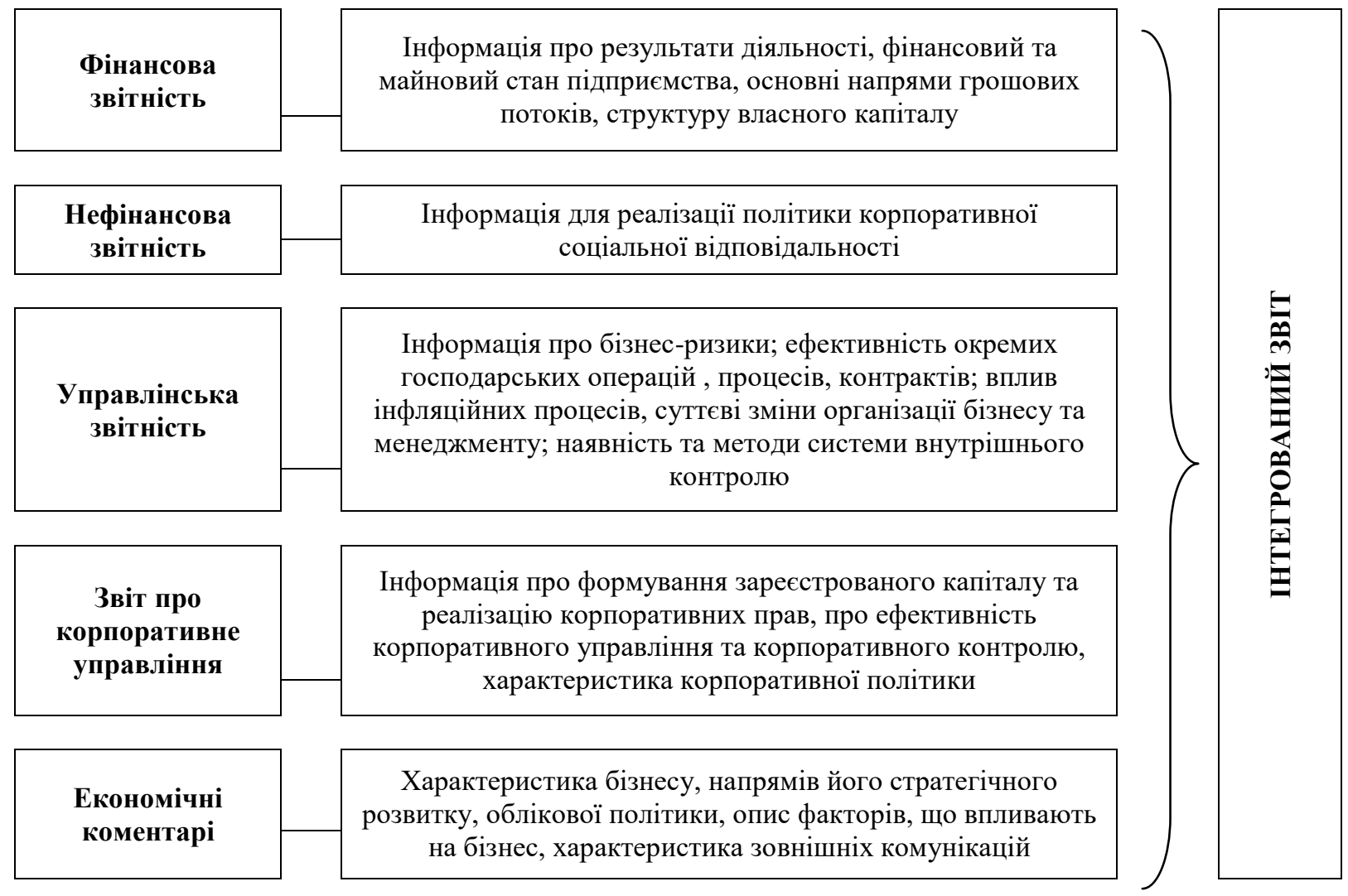

Рис. 1. Формування структури та змісту інтегрованої звітності*

*авторська розробка

Зазначимо, що інтегровану звітність не можна розглядати як механічне поєднання показників тільки фінансової звітності, нефінансових та управлінських звітів. Інтеграція звітності передбачає також розширення інформаційного змісту за рахунок розкриття корпоративних даних та надання економічних коментарів (рис. 1). Такий підхід надає інтегрованій звітності зрозумілості. При цьому корпоративні дані можуть подаватися у вигляді Звіту про корпоративне управління та включають інформацію про формування зареєстрованого капіталу, про ефективність корпоративного управління та корпоративного контролю, характеристику корпоративної політики. Слід звернути увагу на той факт, що в країнах 3 розвиненим ринком капіталу порядок формування змісту та необхідного рівня достовірності корпоративної звітності регулюється на корпоративному рівні [10].

Таким чином, зміст інтегрованого звіту 
підприємства харчової промисловості, який застосовується 3 метою задоволення інформаційних потреб потенційного інвестора, має складатися 3 таких елементів:

1) фінансова інформація про стан та результати діяльності;

2) нефінансова інформація щодо реалізації політики корпоративної соціальної відповідальності (кадрове забезпечення, соціальний розвиток та забезпечення, екологічна безпека, якість продукції тощо);

3) інформація щодо ефективності, можливостей та ризиків бізнесу; управління;

4) інформація системи корпоративного

5) економічні коментарі щодо організаційної структури, бізнес-моделі, корпоративної та облікової політики, характеристики бізнес-середовища й бізнес-комунікацій та напрямів стратегічного розвитку.

Виходячи iз наведеного можна зробити висновок, що інтегрований звіт - це звіт підприємства, який за допомогою фінансових й нефінансових показників та описової інформації надає користувачам прилюдну та достовірну інформацію щодо напрямів та результатів діяльності, можливостей та ризиків, наявності відповідного капіталу (фінансового, виробничого, природного, людського, соціального , інтелектуального тощо), якості корпоративного управління та напрямів стратегічного розвитку задля адекватної оцінки реальної вартості бізнесу.

Означена структура не протирічить Міжнародному стандарту інтегрованої звітності $<\mathrm{IR}>$, який виділяє фундаментальні концепції інтегрованих звітів:

1) надання інформації про ресурси та взаємовідносини (капітали), які використовує і на які впливає організація;

2) прагнення пояснити, як організація взаємодіє 3 зовнішнім середовищем і капіталами для створення вартості протягом короткострокового, середньострокового і довгострокового періоду [11].

Спробами визначити єдині загальні принципи підготовки інтегрованої звітності можна вважати і пропозиції Комітету з Міжнародних стандартів фінансової звітності за документом «Коментарі менеджменту» (Management Commentary) та Директиву щодо вдосконалення звітів Свропейського Союзу (EU Accounts Modernization Directive). Відповідно до peкомендацій Міжнародного комітету 3 інтегрованої звітності (IIRC) у новій бізнес-звітності передбачається розкриття низки показників, що стосуються [12]:

1) огляду організації і бізнес-моделі;

2) опису середовища, в якому працює організація, у тому числі ризиків і можливостей;

3) стратегічних цілей і шляхів їх досягнення;

4) корпоративного управління і винагород;

5) виробничих показників, у тому числі фінансових і не фінансових.

Інтегрована звітність займає важливе місце в системі управління підприємством, адже забезпечує їі своєчасною, достовірною та повною інформацією про поточні та перспективні аспекти бізнесу. В табл.1 представлено зв'язок окремих інтегрованих звітів 3 функціями системи управління.

Таблиця 1

Зв'язок окремих інтегрованих звітів з функціями управління*

\begin{tabular}{|c|l|l|}
\hline Назва звіту & \multicolumn{1}{|c|}{ Основний зміст } & \multicolumn{1}{|c|}{ Функції управління } \\
\hline $\begin{array}{c}\text { Звіт про корпора- } \\
\text { тивне управління }\end{array}$ & $\begin{array}{l}\text { Описує принципи корпоративної та дивідендної } \\
\text { політики, стратегію управління, показники ефек- } \\
\text { тивності корпоративного контролю, характеризує } \\
\text { структуру капіталу }\end{array}$ & $\begin{array}{l}\text { Корпоративний та внутрішньогос- } \\
\text { подарський контроль }\end{array}$ \\
\hline $\begin{array}{c}\text { Звіт про сталий } \\
\text { розвиток }\end{array}$ & $\begin{array}{l}\text { Включає показники ефективності економічного } \\
\text { розвитку, надає характеристику бізнес-моделі, } \\
\text { суттєвих факторів впливу, описує можливості та } \\
\text { ризики бізнесу }\end{array}$ & $\begin{array}{l}\text { Контроль ефективності бізнесу, } \\
\text { контроль рівня економічної безпе- } \\
\text { ки, стратегічне планування }\end{array}$ \\
\hline $\begin{array}{c}\text { Звіт про соціаль- } \\
\text { ний розвиток }\end{array}$ & $\begin{array}{l}\text { Включає показники кадрового та соціального за- } \\
\text { везення, показники реалізації вимог соціальної } \\
\text { відовідальності }\end{array}$ & $\begin{array}{l}\text { Контроль соціальної відповідаль- } \\
\text { ності }\end{array}$ \\
\hline Екологічний звіт & $\begin{array}{l}\text { Включає показники екологічної безпеки випуску } \\
\text { готової продукції та бізнесу в цілому }\end{array}$ & $\begin{array}{l}\text { Екологічний контроль та контроль } \\
\text { якості готової продукції }\end{array}$ \\
\hline
\end{tabular}

*Авторська розробка

На наш погляд, основне завдання інтегрованих звітів для самого підприємства - забезпечити реалізацію функцій корпоративного й внутрішньогосподарського контролю та функцію стратегічного планування шляхом надання повної, різноманітної, адекватної інформації публічного характеру.
Підгрунтям для запровадження в Україні практики інтегрованих звітів є обов'язкове укладання та оприлюднення Річної інформації емітента цінних паперів, зміст якого за 2019 рік передбачає розкриття інформації щодо [13]: 
1) Умови організації діяльності емітента (п. 1-8) (основні відомості, Інформація про одержані ліцензії (дозволи) на окремі види діяльності, Відомості про участь емітента в інших юридичних особах, Інформація про наявність філіалів або інших відокремлених структурних підрозділів емітента; Судові справи емітента; Штрафні санкції.

2) Опис бізнесу (п.9).

3) Інформація про органи управління емітента, його посадових осіб, засновниківтта/або учасників емітента та відсоток їх акцій (часток, паїв) (п.10).

4) Звіт керівництва (звіт про управління) (п.11).

5) Інформація про власників акцій та зміни акціонерів за звітний період (п.12-15) (враховуючи інформацію про власників пакетів 5 і більше відсотків акцій).

6) Інформація про структуру капіталу, в тому числі із зазначенням типів та класів акцій, а також прав та обов'язків акціонерів (учасників) (п.16).

7) Інформація про цінні папери емітента та виплату дивідендів (п.17-23).

8) Інформація про господарську та фінансову діяльність емітента (п.24) (про основні засоби емітента (за залишковою вартістю); щодо вартості чистих активів емітента; про зобов'язання емітента; про обсяги виробництва та реалізації основних видів продукції; про собівартість реалізованої продукції; про осіб, послугами яких користується емітент).

8) Інформація про вчинення значних правочинів (п.25-28).

9) Річна фінансова звітність та аудиторський висновок (п.29-32).

10) Інформація про суттєві договори та/або правочини (п.33-34).

11) Інформація про випуск та забезпечення інших цінних паперів (п.35-45).

12) Примітки до звітної інформації, які подаються за вимогами міжнародних стандартів (п.46).

Зазначимо, що класифікація складових Річної інформації емітента, наведена вище, проведена авторами самостійно для забезпечення наочності та кращого сприйняття структури даної інформації.

Дана інформація має складну структуру, $є$ важкою для сприйняття i тому підлягає критиці зі сторони керівництва підприємств, бухгалтерів, аудиторів та інвесторів. Однак незважаючи на недоліки, цей документ включає елементи нефінансового характеру, якими можна скористуватись у відкритому доступі, адже дана інформація є публічною та підтверджена незалежним аудитом.

Звертаємо увагу на той факт, що опис бізнесу включає обов'язкову інформацію щодо [13]:

1) проблеми, які впливають на діяльність емітента; ступінь залежності від законодавчих або економічних обмежень;

2) опису обраної політики щодо фінансування діяльності емітента, достатність робочого капіталу для поточних потреб, можливі шляхи покращення ліквідності за оцінками фахівців емітента;

3) стратегії подальшої діяльності емітента щонайменше на рік (щодо розширення виробництва, реконструкції, поліпшення фінансового стану, опис істотних факторів, які можуть вплинути на діяльність емітента в майбутньому);

4) іншої інформації, яка може бути істотною для оцінки інвестором фінансового стану та результатів діяльності емітента, у тому числі, за наявності, інформацію про результати та аналіз господарювання емітента за останні три роки у формі аналітичної довідки в довільній формі.

Вважаємо, що складання даної інформації $є$ важливим кроком в процесі запровадження інтегрованої звітності.

Запровадження інтегрованих звітів одночасно викликає низку проблемних питань, а саме:

1) доцільність застосування інтегрованої звітності для підприємств різних розмірів та необхідність врахування витрат на укладання та оприлюднення інтегрованих звітів [3];

2) зростання ризику втрати або послаблення підприємством своїх конкурентних переваг у зв'язку iз розкриттям в інтегрованому звіті інформації про «фактори створення і руйнування вартості, стратегічні аспекти діяльності та існуючі ризики» діяльності [3];

3) формування «нових викликів для аудиту та інших існуючих і супутніх процесів» складання та опублікування інтегрованих звітів [3];

4) відсутність єдиного підходу до складу та змісту інтегрованого звіту та відповідних стандартів. Увага підприємства зосереджена «тільки на тих питаннях, які підприємство вважає найбільш суттєвими для довгострокового успіху» [14]. Отже виникає доречне питання: «наскільки можливо визначити в деталях інформацію, необхідну для розкриття, щоб вона була корисною?» [15];

5) необхідність активного залучення до процесу формування інтегрованої звітності бухгалтерів 3 управлінського обліку [16]. Проблемою є недостатній рівень обізнаності обліковців підприємства 3 питань укладання управлінської та інтегрованої звітності;

6) необхідність застосування інформаційних технологій та інформаційних ресурсів задля розміщення та оприлюднення інтегрованих звітів. Передову позицію у вирішенні цієї проблеми займають ITпідприємства.

Задля розвитку практики застосування інтегрованої звітності ефективним є запровадження спеціальних ініціатив серед рівних груп користувачів [17]:

1) ініціатива підприємств у впровадженні інтегрованої звітності;

2) активна підтримка ініціативи підприємств щодо практики застосування інтегрованих звітів 3 боку інвесторів, фінансових посередників та неприбуткових організацій;

3)розвиток законодавчої ініціативи щодо розвитку інтеграції звітної інформації на фондовому ринку.

Слід зазначити, що чинна система бухгалтерського обліку не забезпечує належну інформаційну підтримку управління вартістю. Відповідно, «тради- 
ційна фінансова звітність $є$ нечутливою до факторів вартості сучасного бізнесу») [18].

Важливим аспектом запровадження інтегрованої звітності є трансформація системи бухгалтерського обліку на підприємстві, задля якої сучасними науковцями рекомендується:

1) розширити кількість капіталів, інформація про які повинна відображатись в інтегрованій звітності,

2) здійснювати розкриття інформації за допомогою грошових і негрошових вимірників;

3) здійснювати розкриття ретроспективної, поточної та перспективної, прогнозної та стратегічної інформації про вартість підприємства;

4) переорієнтація з прибутку до вартості корпоративної структури та факторів, як основної цілі функціонування корпоративної структури [19].

Фактично мова йде про організацію на підприємствах інтегрованого обліку нової формації, який спрошує процедуру укладання інтегрованих звітів.

3 метою формування інтегрованої звітності та запровадження інтегрованого обліку підприємствам харчової промисловості доцільно:

1) розробити за запровадити положення корпоративної політики підприємства щодо формування та подання інтегрованих звітів в системі управління підприємством;

2) розробити та запровадити положення облікової політики підприємства щодо ведення інтегрованого обліку та формування інтегрованих звітів;
3) створити внутрішньо фірмові стандарти ведення інтегрованого обліку та укладання інтегрованої звітності відповідно до вимог Міжнародних стандартів бухгалтерського обліку;

4) розробити документацію для ведення інтегрованого обліку та форми інтегрованих звітів;

5) створити механізм та інструментарій внутрішньогосподарського (корпоративного) контролю в системі інтегрованого обліку та звітності;

6) провести навчальні тренінги для облікового та управлінського персоналу щодо ведення інтегрованого обліку та складання інтегрованих звітів;

7) провести роз'яснювальну роботу серед представників керівництва щодо змісту, значимості та застосування інтегрованої звітності в системі управління підприємством.

Висновки та напрями подальших досліджень. Інтегрована звітність $\epsilon$ новою парадигмою трансформації процесу звітування для сучасних підприємств, особливо у корпоративній сфері. Нові умови економічного розвитку вимагають оновлення методологічних підходів до складання та подання звітності, ведення обліку в умовах формування інтегрованої інформації, розширення функцій управління тощо. Наявність великої кількості проблемних питань даний напрям дослідження дотепер залишається актуальним та передбачає детальне вивчення трансформації системи бухгалтерського обліку та створення внутрішньофірмових стандартів інтегрованої звітності.

\section{Лiтература}

1. Куцик П., Корягин М. Інтегрована звітність як нова парадигма розвитку бухгалтерської звітності // Бухгалтерський облік і аудит. 2015. № 5. С. 11-18.

2. International Integrated Reporting Council ('IIRC'): [Website]. URL: http://www.theiirc.org. (дата звернення: 10.05.2021)

3. Adams S., Simnett R. Integrated Reporting: An Opportunity for Australia's Not-for-Profit Sector. Australian Accounting Review. 2011. Vol. 21. No 3. P. 292-301. doi: 10.1111/j.1835-2561.2011.00143.x

4. Проданчук М.А. Інтегрована звітність - інструмент управління підприємством // Бухгалтерський облік і аудит. 2014. № 2. С. 24-31.

5. Хеннинг Драгер. Интегрированная отчетность должна работать на всех // Экономические стратегии. 2017. № 3. C. 176-185.

6. Романенко О.А., Комірна О.В. Аналіз інтегрованої звітності у забезпеченні сталого розвитку суспільства // Бухгалтерський облік, аналіз та аудит. 2017. № 17. С. 880-887.

7. Словник іншомовних слів. Словопедія. URL: http://slovopedia.org.ua/42/53382/283032.html (дата звернення: 10.05.2021)

8. Томчук В.В. Інтегрована звітність: новий етап у еволюції бухгалтерського обліку // Фінанси, облік, банки. 2017. №1 (22). С. 170-180.

9. Passant F., Hewitt G. What do investors expect from nonfinancial reporting? ACCA, 2013. 12 p.

10. Eccles R. G., Serafeim G. Corporate and Integrated Reporting: A Functional Perspective // Harvard Business School Working Paper. 2014. No. 14-094. P. 1-21. doi: 10.2139/ssrn.2388716

11. The International Framework <IR>. URL: https://bitly.su/lodC. (retrieved from: 12.05.2021)

12. На один шаг ближе к интегрированной отчетности. Новый поход в 21 веке. IIRC: веб-сайт. URL: http://www.labrate.ru/discus/messages/20/IR-Discussion-Paper-2011_single-rus-40803.pdf (дата звернення: 11.05.2021)

13. Положення про розкриття інформації емітентами цінних паперів, затв. Рішенням НКЦПФР від 03 грудня 2013 року № 2826: за станом на 24 квітня 2020p. Законодавство України: веб-сайт. URL: https://zakon.rada.gov.ua/laws/show/z2180-13\#Text (дата звернення: 12.05.2021)

14. Integrated Reporting. The Future of Corporate Reporting. - PricewaterhouseCoopers, 2012. 80 p. 
15. Костюченко В.М., Богатир Н.В. Інтегрована звітність як іноваційна модель звітності корпоративних підприємств України // Глобальні та національні проблеми економіки. Вип. 8. 2015. С. 1126-1130.

16. Busco Cristiano, Frigo Mark L., Quattrone Paolo, Riccaboni Angelo. Redefining Corporate Accountability through Integrated Reporting // Strategic Finance. 2013. P. 33-41. doi: 10.1007/978-3-319-02168-3

17. Eccles Robert G., Serafeim George. Accelerating the Adoption of Integrated Reporting // CSR Index 2011. Editors Francesco de Leo \& Matthias Vollbracht. P. 70-92.

18. Guthrie J., Petty R. Intellectual Capital: Australian Annual Reporting Practices // Journal of Intellectual Capital. 2000. Vol. 1. No. 3. P. 241-251. doi: 10.1108/14691930010350800

19. Царук В. Ю. Концептуальні засади інтегрованої звітності в корпоративних структурах // Ефективна економіка. 2020. № 4. URL: http://www.economy.nayka.com.ua/?op=1\&z=7790. doi: 10.32702/2307-2105-2020.4.74 (дата звернення: 12.05.2021)

Стаття надійшла 17.05.2021

Стаття прийнята до друку 31.05.2021

Доступно в мережі Internet 21.07.2021

Tkachuk H.

Doctor of Economics, Associate Professor

Department of Accounting and Auditing

E-mail: talla2007@ukr.net

ORCID ID: 0000-0001-6937-6223
Ivanchenkova $\mathbf{L}$.

Doctor of Economics, Professor

Department of Accounting and Auditing

E-mail: ivanchenkovalarisa@gmail.com

ORCID ID: 0000-0002-8461-7846

Skliar L.

Ph.D., Associate Professor

Department of Accounting and Auditing

Odesa National Academy of Food Technologies

Kanatna str., 112, Odesa, Ukraine, 65039

E-mail: sklyarlarisa17@gmail.com

ORCID ID: 0000-0002-8332-8823

\section{INTEGRATED ACCOUNTING AND REPORTING IN CORPORATE ENTERPRISE MANAGEMENT: THEORETICAL ASPECTS OF IMPLENENTATION AND CONTROL}

The relevance of the direction of the scientific research is justified by the expansion of information needs of reporting information in the context of globalization processes. The financial statements of the company no longer meet the current needs of users in reporting information and does not allow to reliably determine the fair value of the business, to fully assess its opportunities and risks.

The article is devoted to the study of the problems of formation of the theoretical and methodological basis of the application of integrated accounting and reporting in corporate enterprises. To achieve the result, the authors used general and special research methods (abstract thinking, analysis, synthesis, data systematization, generalization of results, etc.).

The essence, purpose and tasks of the integrated reporting have been defined, its distinctive features from the traditional financial reporting have been analyzed; the prerequisites for the development of the integrated reporting model have been considered. The place of integrated reporting in the enterprise management system, the connection of individual integrated reports with the management functions in the food industry have been determined.

This article summarizes the problematic aspects of the application of integrated reporting for corporate enterprises. The peculiarities of the formation of the structure and content of integrated reporting, as a combination of financial and non-financial reporting information, corporate data and economic comments have been determined.

The analysis of the structure and content of the annual information of the corporate enterprise - the issuer of securities, has been carried out and the classification of the components of this information has been carried out, according to the tasks, the solution of which is entrusted to the integrated reporting. The authors propose measures for the practical application of integrated accounting and integrated reporting in the enterprise. The directions of further research on the introduction of integrated accounting and reporting in the corporate enterprise management system have been identified.

Key words: accounting, integrated accounting, financial reporting, integrated reporting, International Accounting Standards, internal standards, corporate control, internal control, enterprise management. 


\section{References}

1. Kutsyk, P., \& Koriahyn, M. (2015). Intehrovana zvitnist yak nova paradyhma rozvytku bukhhalterskoi zvitnosti. Bukhhalterskyi oblik $i$ audit, (5), 11-18.

2. International Integrated Reporting Council ('IIRC'). http://www.theiirc.org.

3. Adams, S., \& Simnett, R. (2011). Integrated Reporting: An Opportunity for Australia's Not-for-Profit Sector. (Australian Accounting Review), 21(3), 292-301. doi: 10.1111/j.1835-2561.2011.00143.x

4. Prodanchuk, M. A. (2014). Intehrovana zvitnist - instrument upravlinnia pidpryiemstvom. Bukhhalterskyi oblik $i$ audit, (2), 24-31.

5. Henning Drager (2017). Integrirovannaya otchetnost dolzhna rabotat na vseh. Ekonomicheskie strategii, (3), 176-185.

6. Romanenko, O. A., \& Komirna, O. V. (2017). Analiz intehrovanoi zvitnosti u zabezpechenni staloho rozvytku suspilstva. Bukhhalterskyi oblik, analiz ta audit, (17), 880-887.

7. Slovnyk inshomovnykh sliv. Slovopediia. http://slovopedia.org.ua/42/53382/283032.html

8. Tomchuk, V. V. (2017). Intehrovana zvitnist: novyi etap u evoliutsii bukhhalterskoho obliku. Finansy, oblik, banky, (1(22), 170-180.

9. Passant, F., \& Hewitt, G. (2013). What do investors expect from nonfinancial reporting? ACCA, 12 p.

10. Eccles, R. G., \& Serafeim, G. (2014). Corporate and Integrated Reporting: A Functional Perspective. (Harvard Business School Working Paper), No 14-094, 1-21. doi: 10.2139/ssrn.2388716

11. The International Framework $\langle I R\rangle$. https://bitly.su/lodC.

12. $\mathrm{Na}$ odin shag blizhe $k$ integrirovannoy otchetnosti. Novyiy pohod $v 21$ veke. IIRC. http://www.labrate.ru/discus/messages/20/IR-Discussion-Paper-2011_single-rus-40803.pdf

13. Polozhennia pro rozkryttia informatsii emitentamy tsinnykh paperiv, zatv. Rishenniam NKTsPFR vid 03 hrudnia 2013 roku № 2826: za stanom na 24 kvitnia 2020 r. Zakonodavstvo Ukrainy. https://zakon.rada.gov.ua/laws/show/z2180-13\#Text

14. Integrated Reporting. The Future of Corporate Reporting. (2012). PricewaterhouseCoopers, 80.

15. Kostiuchenko, V. M., \& Bohatyr, N. V. (2015). Intehrovana zvitnist yak inovatsiina model zvitnosti korporatyvnykh pidpryiemstv Ukrainy. Hlobalni ta natsionalni problemy ekonomiky, (8), 1126-1130.

16. Busco Cristiano, Frigo Mark L., Quattrone Paolo, \& Riccaboni Angelo (2013). Redefining Corporate Accountability through Integrated Reporting. Strategic Finance, 33-41. doi: 10.1007/978-3-319-02168-3

17. Eccles Robert G., \& Serafeim George. Accelerating the Adoption of Integrated Reporting. CSR Index 2011, 70-92.

18. Guthrie, J., \& Petty, R. (2000). Intellectual Capital: Australian Annual Reporting Practices. Journal of Intellectual Capital, 1(3), 241-251. doi: 10.1108/14691930010350800

19. Tsaruk, V. Yu. (2020). Kontseptualni zasady intehrovanoi zvitnosti v korporatyvnykh strukturakh. Efektyvna ekonomika, (4). http://www.economy.nayka.com.ua/?op=1\&z=7790. doi: 10.32702/2307-2105-2020.4.74

Received 17 May 2021

Approved 31 May 2021

Available in Internet 21.07.2021

Цитування згідно ДСТУ 8302:2015

Ткачук Г.О., Іванченкова Л.В., Скляр Л.Б. Інтегрований облік та звітність в управлінні корпоративного підприємства: теоретичні аспекти запровадження та контролю // Економіка харчової промисловості. 2021. Т.13, вип. 2. C. 87-94. doi: $10.15673 /$ fie.v13i2.2044

Cite as APA style citation

Tkachuk, H., Ivanchenkova, L., \& Skliar, L. (2021). Integrated accounting and reporting in corporate enterprise management: theoretical aspects of implementation and control. Food Industry Economics, 13(2), 87-94. doi: 10.15673/fie.v13i2.2044 